\title{
Following Policy: Networks, network ethnography and education policy mobilities.
}

\section{Stephen J Ball}

Mobile policies . . . are not simply travelling across a landscape - they are remaking this landscape, and they are contributing to the interpenetration of distant policymaking sites. (Peck and Theodore, 2010 p. 170)

... the new strategic cosmopolitan serves as a nodal agent in the expanding networks of the global economy (Mitchell 2003).

\begin{abstract}
Based on the 'case' of educational reform in India this paper explores the emergence of both new trans-national spaces of policy and new intra-national spaces of policy and how they are related together, and how policies move across and between these spaces and the relationships that enable and facilitate such movement. The paper is an attempt to think outside and beyond the framework of the nation state to make sense of what is going on inside the nation state. In particular, it takes seriously the need to rethink the frame within and scales at which the new policy actors, discourses, connections, agendas, resources and solutions of governance are addressed - and the need to move beyond what Beck calls 'methodological nationalism' (Beck 2006). In other words, the paper argues that thinking about the spaces of policy means extending the limits of our geographical imagination. To address this argument it combines the presentation and discussion of data with some more general discussion of policy networks and mobilities.
\end{abstract}

\section{Introduction}

This paper explores the emergence of both new trans-national spaces of policy and new intra-national spaces of policy and how they are related together, and how policies move across and between these spaces (Schriewer 2014), and some of the relationships that enable and facilitate such movement. Borrowing the term from one of the research respondents (see below), it takes what he called the Indian Education Reform Movement (IERM) as a case in point and as a focus for the discussion of policy networks and policy mobilities,. The IERM is one of many new 'complex and contradictory spaces ripe for critical interrogation' (Peck and Theodore 2012 p. 21). The paper is an attempt to think outside and beyond the framework of the nation state to make sense of what is going on inside the nation state - and the 
need to move beyond what Beck (2006) calls 'methodological nationalism'. In particular, it takes seriously the need to rethink the frames within and scales at which new education policy actors, discourses, conceptions, connections, agendas, resources and solutions of governance are addressed. In other words, thinking about the spaces of policy means extending the limits of our geographical imagination. It also means attempting to grasp the joining up and re-working of these spaces in and through relationships.

From Peck and Theodore (2010) I adopt the term 'policy mobility'. Policies are mobile not in distinct and compact forms or 'bundles' but rather in a piecemeal fashion. They are (re) assembled in particular ways, in particular places and for particular purposes (McCann and Ward 2012). Nonetheless, I also suggest, at least in relation to education policy, that these re-assemblies may have convergent consequences in terms of modes of governance and global forms and conceptions of policy that require us to think both about how the 'global' impacts on the 'national', while acknowledging, at the same time, the extent to which the national is critical in the formation of global policy agendas. However relatedly, like other geographers of policy, I want to escape from the artificiality of 'levels' as distinct boundaries of political activity and the global and local as a binary and instead emphasise the interdependency of actors and the movement of ideas in the framing of problems and policy directions and conceptions (Grek and Ozga 2010). This is what Freeman described as living in Galton's world, 'a world of international interdependence, of the continuous, reciprocal reproduction of global and local ...' (quoted in (Grek 2013)), a world of 'promiscuous entanglements of global and local logics' which 'crystallise different conditions of possibility' (Ong 2007 p.5). All of this means attending to; multiple sites, spaces and scales of policy within and between states and the interactions, relations and movements between them; both national and local unevenness and frictions; urban/rural differences; and different speeds of change and moments of possibility in different localities. This aligns with what (Lingard and Sellar 2014), drawing on (Amin 2002), call a 'topological approach', which focuses on the 'new topological spatialisations associated with globalisation' and in turn it is concomitant with the tropes and method of network analysis. The challenge is to understand the reconfiguration of policy spaces and the movements and flows in and across this new terrain. So I am going to attempt some resolution between network analysis - and its emphasis on structural relations - and the analysis of policy mobilities - which draws our attention to flows.

\section{Network analysis and Network Ethnography}

In a series of studies with colleagues (Ball 2013, Junemann etal 2015, Santori etal 2016, (Olmedo, Bailey et al. 2013)), I have begun to explore some of the 
interdependences and mobilities referred to above, focusing in particular on the increasing role of businesses and philanthropy in education policy work, deploying the trope of a global policy network ${ }^{i i}$ (see Figure 1 ) as an analytical and representational device. This involves both a mapping of and representation of the 'global education policy field' (Lingard and Rawolle 2011), and the use of network ethnography as a method for researching mobilities and interactions within the network. Through the work of this network policy is both being moved and fixed. To understand how this is achieved we have to attend to the relationships, events and exchanges that make up network activity and evolution. In other words, we have to focus on the labour of network actors. Networks are not just a set of connections between sites but are also a history of on-going effort, and are animated by social relations and performance. For example, at network events and meetings programmes are 'pitched', policy stories are told, commitments (some of them financial) are made, and new arrangements and relationships established (like the founding of The Education Alliance - see below). In other words, 'Sites in translocal assemblages have more depth than the notion of 'node' or 'point' suggests (as connoted by network)' (MacFarlane 2009). Network nodes are the focus for various forms of local activity, animation and discourse proliferation (see Ball 2016). Some of that depth will be illustrated here drawing on the Indian case.

Some trans-national policy players within the global education policy field are well researched, like the OECD, World Bank and European Union; in comparison edubusinesses (Bhanji 2012, (Hogan, Sellar et al. (forthcoming)), Ball 2012, Ball etc 2015, Junemann and Ball $2015^{\mathrm{iii}}$ ), Ed-Tech companies (Santori 2016), foundations and philanthropies and social enterprises (Reckhow 2013), Auv (Kretchmar, Sondel et al. 2014), (Olmedo, Bailey et al. 2013)) have received much less attention from researchers. Nonetheless, the latter are now clearly having significant impact on the formulation and reformulation of teaching and learning, assessment and the curriculum and the general directions and conceptualisation of education policy and governance within and across national jurisdictions (Hogan 2015).

Network Ethnography (see Ball 2012) is a developing method of research (or an assemblage of research tactics and techniques) that engages with this new policy topography. It involves mapping, visiting and questioning and as (Marcus 1995) puts it - following policy. That is, following people, 'things' (blended learning, assessment, PPPs -(Verger and Curran 2014)), stories, lives and conflicts and 'money' (Junemann, Ball and Santori 2016). It involves, as Peck and Theodore (2012 p. 24) put it 'judicious combinations of ethnographic observation and depth interviewing', which are essential to 'any adequate understanding of the inescapably social nature of those continuous processes of translation, intermediation, and contextualization/decontextualization/recontextualization, through which various 
forms of policy mobility are realized'. Network ethnography involves close attention to organisations and actors, and their relations, activities and histories, within the global education policy field, to the paths and connections that join-up these actors, and to 'situations' and events in which policy knowledge is mobilized and assembled. That is, the 'whos' and 'whats' but also the 'where's' of policy - the places and events in which the 'past, present and potential futures of education co-exist' (McCann and Ward 2012 p. 48). This involves an ethnography of 'awkward scale' as Roy (2012 p. 37) puts it. In general terms, network ethnography addresses 'the people, places, and moments' (Prince 2010) involved in the making and remaking of mobile policies and attempts to identify the paths and pipelines, and nodes and activities through which policy moves, and the discourses and culture which articulate the policy community it represents. We need to ask: What spaces do policies travel through on the way from place to another? Who is it that is active in those spaces and who moves between them? How is space/are spaces reconfigured as policies move through it/them and how are policies changed as they move? As McCann and Ward (2012 p. 42) put it, this means both 'following policies and "studying through" the sites and situations of policymaking'. As regards the who, they go onto explain: 'Our work asks how policy actors circulate policies among cities, how they draw on circulating policy knowledge and how and for whom they put these engagements to use as they assemble their own 'local' policies...' (p. 42). All of this means 'staying close to practice' (McCann and Ward 2012 p. 45) and 'tracing the travels of policies and actors'. While there has been a burgeoning of interest in mapping education policy networks, there are relatively few examples of direct research on the effort and labour of networking, or which 'follows' policy through networks, or addresses the work and movement of key actors (see Nambissan and Ball 2010, Hogan 2015) or which attends to network evolution. There is a considerable leap involved in the shift from mapping network relations to analyzing network dynamics.

In this study the deployment of the method of network ethnography, very much like what Peck and Theodore (2012 p. 24) call 'the distended case study approach', has involved 'a judicious combination of observations, documentary analysis, and depth interviews' (p. 24); deep and extensive internet searches (focused on actors, organisations, events); attention to related social media, blogs, podcasts, twitter and website documents; interviews with nodal actors within the network (12 interviews are of direct relevance in the case here although others were undertaken - see below); and attendance at network events (e.g. in this case WISE (Dohar), SANKALP (Mumbai), PALF (Johannesburg and London) meetings and the mEducation Alliance Symposium (Washington $)^{v}$ ). These data are used here both to map and build the network, identified 'connections' were recorded and logged onto a data base, and as the basis analysis of the work of networking - the labour of policy actors (See Ball 2012). The former involved the use of NodExel software to create a data base of 
organisations, programmes and people identified as network members through searches and in the interviews and then to display the relationships between members in pictorial form (see Figure 1). The latter drew on the interview and social media and events data to make sense of the relationships, types of interactions and outcomes, of the labour of networking. Policies were 'followed' through the network by identifying key events and moments, key nodal actors (boundary spanners and policy entrepreneurs), significant mobile transnational and glocal actors, and the social relations that join these up.

Policy networks and policy mobilities in India ${ }^{\text {vi }}$.

What follows is an overview rather than a comprehensive analysis of network relations and network activities as they relate to (some aspects) of education reform in India. It is impossible to convey the scope and scale of even this part of the network and its diversity of constituents and activities in the space available. Furthermore, each of the participants and policy examples discussed below warrant further analytic attention. As a result issues like the glocalisation and re-assembly of policy in this setting are given fairly cursory attention in this paper and will be the focus of further work. For the moment I am hoping to establish a framework within which further analysis can be done. I identify for discussion four loosely bounded, inter-related facets of the social and policy relations of the IERM; homophily, social relations, global forms and a dispositif of governance. As presented each builds upon and elaborates the previous ones. The IERM is a close, informal, diverse but effective group of policy actors who are seeking to bring about change in India's school system (see below). However, to be clear this is not the be all and end all of current education policy activity in India. This is one field, or one sector of the contemporary topography of education policy, which intersects and overlaps with other fields and sectors both national and global.

Table 1 lists the key actors in the Indian Education Reform Movement (IERM) and those named have all been interviewed for the research, some other more peripheral actors who have been interviewed are not included here. The Indian part of the global education policy network is shown in Figure 2.

Table 1: Key participants in the Indian Education Reform Movement

\begin{tabular}{|l|l|}
\hline DfiD & $\begin{array}{l}\text { Michael and Susan Dell Foundation } \\
\text { (Prachi Windlass) }\end{array}$ \\
\hline McKinsey (Ramya Venkataraman) & Teach for India (Tomos Davies) \\
\hline Ark (India) (Amitav Virmani) & Omidyar Network \\
\hline
\end{tabular}




\begin{tabular}{|l|l|}
\hline Centre for Civil Society (Prath Shah) & $\begin{array}{l}\text { Central Square Foundation (Ashish } \\
\text { Dhawan) }\end{array}$ \\
\hline Azim Premji Foundation (Anurag Behar) & Bharti Foundation \\
\hline Akanksha Foundation (Vandana Goyal) & Indian School Leadership Institute \\
\hline $\begin{array}{l}\text { STIReducation (Sharath Jeevan, James } \\
\text { Townsend) }\end{array}$ & $\begin{array}{l}\text { Pearson Affordable Learning Fund } \\
\text { (Ember Melcher, Sir Michael Barber) }\end{array}$ \\
\hline
\end{tabular}




\section{Speaking with one voice}

The network is denoted by a high degree of homophily - mobilised around, in different degrees of stridency, critiques and concerns about the efficacy of the state ${ }^{\mathrm{vii}}$ and the ineffectiveness of public education and over and against this an adherence to 'causal stories' (Stone 2004) and 'silver bullets' (Ball and Olmedo 2012) that offer 'solutions' to these failures. PPPs are one such silver bullet, entrepreneurship and leadership are others and measurement and outcomes driven reform a fourth (see below). Very simply the networks include 'anyone who understands that non-state solutions have a place at the table when it comes to the goal of education for all' (Ember Melcher)(EM). While (Ong and Collier 2005) argue that '(a)n assemblage is the product of multiple determinations that are not reducible to a single logic', I would suggest that there is a coherent logic and shared epistemic sensibility to the 'bundle' of policy ideas that circulate and are reiterated within the network. This is a neoliberal rationality (see (Ball 2013)) that deploys the techniques of investment, business innovation and performance management as methods for the re-culturation and reform public education. That is to say, 'Networks contribute both to creating the preconditions for mobilization and to providing the proper setting for the elaboration of specific world-views and lifestyles' (Della Porta and Diani 1999 p. 14).

Some sense of this logic, and the sensibilities and worldviews to which it gives rise can be conveyed by focusing on Ashish Dhawan (AD) He is founder of the Central Square Foundation (CSF), venture capitalist turned venture philanthropist and is a key 'labourer' and boundary spanner (Ball and Junemann 2012) in this network. CSF funds and supports Akanksha, Teach for India and the India Institute of School Leadership among many other organisations, and was involved in setting up The Education Alliance (http://www.theeducationalliance.org) (jointly with ARK, Dell and Omdiyar),

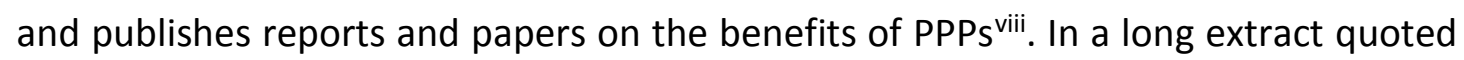
below Dhawan explains the general approach adopted by the network in using business methods and sensibilities to bring about educational innovation and change. He also outlines the crucial role of venture philanthropy in funding new policy 'solutions' and the mobilisation of national and international actors in a joined-up approach to educational reform - a process of getting 'problems' recognised and 'solutions' validated through lobbying and persuasion. A variety of accumulated skills and capitals from business are 're-invested' in the mobilisation of education reform. He explained:

I approach the education problem, or education crisis, in India much like a business problem, so strategic thinking, looking at the problem as an investor; 
comparing the Indian system with other systems in the world, figuring out, what the top priorities ought to be if you were to change the system, looking at what the challenges are. The same way we'd approach a business problem and figure out what's the near-term objective, what's the medium-term objective and what we can do over the long-term.

The second one is I was an investor, I did private equity venture capital style investing, I know how to select entrepreneurs, I know how to work with them, how to define metrics, hold them accountable. We make grants to existing organisations but we also incubate new non-profits, and so there my private equity experience is quite useful.

Third area is with regards to evangelising the cause of education, amongst the business community, and other stakeholders who aren't aware of how bad the situation is (and) why they need to be more deeply invested in it; doing the same with media, getting them to understand why they need to write more on this issue and take this more seriously. Talking to US foundations and getting them more interested in working in this space in India. Talking to ed. reformers around the world to see if they want to extend their business models to look at India.

A fourth one is, we had to use our persuasion skills to convince investors/entrepreneurs around a whole bunch of things. I want to bring some of that to bear. Again, the ability to do research, build a cogent argument, be able to argue a point of view out and be able to push or advocate a point of view.

Here we see some key facets of the network discourse, some of its participants, and the 'methods' of policy work employed, and its global scope. At the same time, one form of policy mobility signalled here, that from business to education reform. Business thinking and sensibilities are deployed to re-work the sensibilities and reimagine the methods of education policy.

The discursive coherence of the network is maintained by reiteration at network events and the creation of new policy microspaces - like The Education Alliance, which is a joint venture by CSF, Dell, Omidyar and ARK - within which sensibilities are fostered and 'solutions' are deployed.

The focus of education leaders in India is moving away from enrollment to quality. Indian parents are choosing private schools over public schools, but these don't always address issues of equity. New models of schooling are 
urgently needed to provide high quality education to the disadvantaged. PPPs offer an opportunity to leverage the combined strengths of the government and the private sector to address some of these issues. (Education Alliance Website)

The movement and legitimation of discursive coherence also rests on the network mobility and capitals of nodal actors like Ashish Dhawan. He is a 'mover and shaker' (Williams 2002) and 'switcher' (Castells 2004), 'managing within inter-organisational theatres' as Williams (2002 p. 104) puts it. He joins up different sectors, moves ideas between them, and initiates policy conversations, establishing and mediating social relations. He advocates and through CSF funds 'solutions', and he is a key source of the articulation of a discourse of 'crisis' and reform. Sharath Jeevan (SJ) (founder of STIReducation), another UK based boundary spanner also active in the network, and constantly in movement between UK, US and India, offered a specific an example of 'switching' and joining-up and 'moving and shaking'. This also gives some sense of the level of policy 'access' at which the network operates and the significance of interpersonal relations in 'getting things done'. Here relationships are made, services and support elicited, and opportunities recognised (see below).

Gordon Brown (ex-UK Prime Minister) came as the UN special envoy for education to India as part of a business delegation there. So Ashish (Dhawan) hosted a dinner. The other thing that happened was that Justin van Fleet ${ }^{\mathrm{ix}}$ was on our advisory board, was actually helping advise Gordon Brown directly. And he said (to Brown), 'you know, STIR's got schools and innovative teachers here, I'm sure the business community might find this interesting as a way of engaging directly with what's happening in schools'. And so we organised a half day for them to come along to visit three or four of our innovators actually in action. (Sharath Jeevan)

Ashish Dhawan sits as trustee on many Third Sector boards in India and elsewhere and is member of some government committees. He is deeply 'embedded' in different policy communities. Boundary spanners like Dhawan tend to have high volumes of network capital generated from and re-invested in inter- and intra-organizational connections. (Urry 2007) defines network capital as 'the capacity to engender and sustain social relations with those people who are not necessarily proximate and which generates emotional, financial and practical benefit ... Network capital ... is a product of the relationality of individuals with others and with the affordances of the 'environment" (p. 198). Dhawan and Jeevan have accumulated, as they have moved, between sectors, countries, events etc. (see below) a considerable volume of 'network capital' which is re-invested, in both practical and discursive forms, in the Indian 
reform movement. They also serve as points of coherence and espousal and part of their capital is evident as trust.

Coherence and adherence rest upon relations of trust. An extensive literature in the field of business research (see (Stuart and Sorenson 2003) indicates the crucial role of networks, network embeddedness and structural diversity in 'shaping the entrepreneurial process and outcomes' in their relation to trust, reputation, opportunity recognition, referrals and therefore access to funding. All of these are very evident in the setting up and growth of Akanksha, STIReduation and Teach for India (see below). This is what Stark (1998) calls the 'biology of business' - forms of bridging and bonding, that build reputations and 'create value' (p. 215) and translate into entrepreneurial success. All of these qualities and relationships are equally relevant and important in doing discursive policy work. Reputation and social relations (both accumulated over time) can be converted into policy credibility. Furthermore, network capital generates a certain sort of expertise that can be deployed in persuasive performances in both intimate and public arenas. Persuasion is important. This involves speaking, explaining, justifying policy ideas, the work of 'framing and selling' (Verger and Curran 2014), discursively reworking policy agendas, joining up previous policy ideas to new ones, and recognising or opening up new policy opportunities. Nodal actors (like AD and SJ) within the IERM network are key to the evolution and maintenance of the network - like the founding of The Education Alliance.

Ashish Dhawan is doing a great job in terms of being able to, you know, get these conversations started and crystallised. They're (CSF) doing a great job, as a policy think tank almost, where they are being able to bring more and more information, more and more informed research to the people based on which they can influence such decisions to be taken. (Prachi Windlass (PW) in charge of the Michael and Susan Dell Foundation's education work in India)

Individual trajectories and histories become embedded in the network, and focussed at particular nodal points. Individual actors bring a history of ideas and relationships with them when they join a network, which are always only partly represented in network relations. These are in effect embodied policy mobilities (Larner and Laurie 2012). People (like Ashish Dhawan, Sharath Jeevan, Prachi Windlass, Vandana Goyal (VG), Prath Shah (PS) - who are also part of a returning global Indian diaspora) move between sectors and places locally and globally, accumulating discursive histories and attendant discourses, sensibilities and practices, these histories are then reembedded and re-contextualised in India. These people bring global forms and articulate policy epistemologies through 'a mixture of previous pathways of interconnection and more contingent (and chance) intersections' (Cook and Ward 
2012 p. 141).

I actually come from management consulting and engineering background. I started my career in engineering, and attended management school in Chicago, moved back to India and worked in management consulting. And around that time is when I started thinking about how can I actually create an impact in a sustainable fashion to improve the learning outcomes of children living in urban India. (PW)

I started off working at Citizen Schools (Boston) and was looking to work here in India for initially just a year and so was looking for good organisations and stumbled across Akanksha. And so came here and then, you know, was enjoying my work so decided to stay for two years. (VG)

I ran something called Teaching Leaders ${ }^{\mathrm{x}}$ in the U.K - and ARK was one of the first donors to that programme - looking to raise the quality of leadership in challenging inner city schools in this country. I was born in India, I spent a lot of time in India when I was a kid. We used to go back to India a lot though, actually, and it was always just very striking, just seeing some of the poverty/deprivation that was happening there, and a clear sense of guilt, ever since I was a child around that. So I'd always wanted to do something that made some kind of difference. I did economics as an undergraduate and I decided to do the conventional thing and go into the City and was a management consultant for quite a while but knew at some point I wanted do something in the social sector. I worked for Action Aid but it wasn't really for me either. So I set up an early version of Facebook. I realised I loved entrepreneurship. This didn't work, it was a classic dotcom story but I loved the process of setting something up and seeing it take off and a new idea coming to life, so I knew I kind of wanted to do that in the social sector. (SJ)

In effect, these actors do the work of 'anchoring globalisation' (Rankin 2003 p. 709) in an uneven topography of trajectories that cross or engage each other to different extents over time (Bennett 2005). We might think about some of these actors as 'travelling technocrats', they are 'embodied actors who knowingly create careers for themselves through and against broader political-economic processes and national imaginaries' (Larner and Laurie 2010 p. 219). However, as Bennett suggests this raises questions about causality and responsibility. We cannot 'explain' the work of the network simply in terms of either its homophily or the agency of members but have to take into account the ongoing relationships and exchanges, the milieu, the occasions and events, in and through which discourse and relationships inhere and evolve. 


\section{The social in social relations}

As evident already, the IERM draws on a variety of direct interpersonal social relations, various kinds of meetingness (Urry 2003), and high levels of trust.

I think informally we do interact with each other, we get invited to each other's programmes and events or discussions within the organisation itself. And, of course, in the case of Ashish, he's also chairman of my board (Centre for Civil Society). (PS)

Over time members of this 'small community' have come to know each other well, they work together and share the values which inform their choices and commitments; and they generate and share persuasive arguments that can be used in more hostile contexts (Grek 2013, p. 56). They meet regularly both formally and informally and are involved in various forms of cooperation and exchange in relation to specific policy projects. All of this is underpinned, enabled, and grown through other social interactions - conversations, meetings, social events, and friendship histories. These relationships and interactions serve to increase and maintain network robustness (See (Owen-Smith and Powell 2004). Conferences, workshops, discussion groups are occasions for the reiteration, reinvigoration, and re-affirmation of discourse and allegiances, a shared language is borrowed/developed to re-name the social. I want to be-labour this point because the social in social networks is often poorly attended to.

I knew many of the people in that initial group of founding supporters that supported Teaching Leaders, I knew them personally, and a lot of trust was built up. And if I'm being honest with you, they were probably backing also the personal side of it as well as the idea as well. (SJ)

And so we started this small group, which is a rather informal group, where we...where we fix up a date when eight/ten/twelve people can come together for a day and we talk about, you know, what we have done in the last few months. There's a meeting actually next month in Bombay. (PS)

Ramya Venkataraman (RV) (Leader of McKinsey \& Company's Education Practice in India) explained progress made and the further developments required:

I absolutely see myself as part of an Indian education reform movement. Now, do I recognise a concrete movement or a group of people or an entity yet? I think yes and no. I think we all are reasonably networked with each other and 
we keep involving each other on various things that we are doing. And, to that extent, yes, you can say it's a loose network, which is serving as a movement. I think we still have some way to go in terms of really synergising and creating a movement out of it. So I don't think it is there yet. It is happening in a somewhat loose and informal manner.

New members are typically enrolled through existing social relations and the same time establish links to other organisations and people, increasing network connectivity and density.

I got a chance to join the fellowship programme in India (through IDEX).

IDEX was started by a company called Gray Matters Capital. It's one of Bob Pattillo's ${ }^{x i}$ many initiatives (...) I was using the network that I had started creating in the IDEX fellowship of researchers and other social enterprises, sometimes even other investors who were working in low-cost education, and, introducing PALF and explaining the kind of deals that we were looking for, and getting connections that way. It was actually another Gray Matters Capital connection that got me the Pearson job. Ross Baird (Executive Director of Village Capital) had a relationship through Gray Ghost Ventures and Indian School Finance Company. I had known Ross ever since college; I met him in my junior year. (EM)

The network is means and end, constantly evolving, expanding and mutating, it is an architecture of social relations, 'girders' and 'pipes' and 'circulatory systems that connect and interpenetrate' the local and the national (Peck 2003 p. 229). The network is animated and joined-up by activity, social interaction, purposeful effort. It is the product of interrelations 'constituted through interactions, from the immensity of the global to the intimately tiny' (Massey, 2005 p. 9).

I actually just had a meeting with Central Square last week in Delhi, to learn more about the initiatives that they're doing. We're always looking for organisations that approach education the way we do, so I also know Sharath (SJ) from STIR very well too. PALF is ... looking at relationships with DFID in India; maybe also something in Pakistan with DFID, based on previous work that Katelyn Donnelly ${ }^{\mathrm{xii}}$ and Michael Barber ${ }^{\mathrm{xiii}}$ have done with DFID in Pakistan. (EM)

Through social relations ideas are shared and borrowed and moved, stories are told and re-told, visits ('policy tourism' McCann calls them) are undertaken, new opportunities to participate or garner support or obtain funding are created. These are conduits of policy mobility. 
I was in Kenya last year for a bit. And they were very supportive actually. And one of the incredibly interesting things about Bridge (BIA) is, whatever you think of the model... because they standardise things so much it's actually quite interesting as a lab really to try new practices ... So we're just having an interesting discussion with Jay (Kimmelman ${ }^{\text {xiv }}$ (SJ)

In the interviews there were frequent references by each interviewee to the others. At the same time, as we see, this 'local' network is thoroughly connected globally to a vast, sprawling, complex set of social and policy relationships. The network combines local actors (CSF, CCS, Akanksha, The Education Alliance, Teach for India etc), mobile actors and global organisations (STIR, PALF) and local representatives of global 'players' in education policy - (McKinsey, Pearson, ARK, MSDF, Boston Consulting, Pearson and others) - within both intimate and more distant chains of relations ${ }^{\mathrm{xv}}$. The local actors are not just learners or recipients they are active within the global education policy network. These locals are involved in re-making the Indian education policy space as active mediators between the global and the national (and local) (Grek 2013 p. 699). As noted above, the India diaspora are important here, as returners, either born abroad (SJ, VG) or who have worked or studied abroad (AD, PW, PS), who carry policy ideas and network relations back with them. Policy visitors and tourists (Gordon Brown, Mike Fienberg (KIPP), Chester Finn (Fordham), Jay Kimmelman (Bridge International Academies) etc. etc.) also bring ideas with them and learn about new developments and opportunities. Business, philanthropy, policy and delivery constantly overlap and inter-relate.

\section{Moving global forms}

While the network interrelates persons and organisations it also joins up and facilitates the mobility of certain global forms - practices and methods of policy - like assessment and data analytics, PPPs, impact measurement, charter schools/academies, blended learning, entrepreneurship and leadership. Artefacts, schemes, programmes, ideas, propositions and 'programmatic' ideas (Verger 2012) move through these network relations, at some speed, gaining credibility, support and funding as they move, mutating and adapting to local conditions at the same time often treated separately and re-assembled on-site. '... (N)ew ideas, fads, and fashions ... New policy ideas, especially "ideas that work," are now able to find not only a worldwide audience but also transnational salience in remarkably short order' (Peck and Theodore 2015, back cover).

These 'global forms' are phenomena that are distinguished by their 'capacity for decontextualization and recontextualization, abstractability and movement, across diverse social and cultural situations and spheres of life' (Ong and Collier, 2005 p. 7). 
The network connections make it possible to trace the movement of practices and methods of policy. For example, in the following extract the 'import' for forms of and ideas for assessment (a Framework and Toolkit) from England is explained, this involves state, third sector and business 'expert' partners, global and local, working with an Indian state government to re-assemble these forms.

ARK, with support from DFID, has developed a School Quality Assessment Framework and tool kit for the Government of Madhya Pradesh to undertake independent, impartial and whole school quality assessments for all the schools. Established to have a state wide Impact, the framework takes into consideration international and national best practices on school assessment models as well as the current work undertaken by the state on school quality improvement. The framework itself has been rigorously developed through a collaborative exercise with a consortium of credible partners such as CfBT, MCRIL $^{\text {xvi }}$ and experts on school quality improvements such as OFSTED UK. ${ }^{\text {vii }}$

Assessment recurs, and in a recent article Ashish Dhawan argued that Indian should follow the model of Obama's 'Race to the Top' - and refocus policy on performance outputs rather than budget inputs. Assessment and impact (http://www.akanksha.org/akanksha-impact-report-2012-2013) and blended learning ${ }^{\text {xviii }}$ are forms and practices that have been adopted and adapted for local use by Akanksha and other Indian education foundations. Impact and effectiveness measurement are also ingrained in the practice of venture philanthropy. In a recent article in The Mint Prachi Windlass explained:

It's actually for us like the DNA of the Michael and Susan Dell Foundation. Basically, I mean, to be very outcomes-focused and results-oriented, comes from our founders, so Michael and Susan are extremely outcomes-oriented. And they were very clear that whatever philanthropic work they were doing they wanted to ensure that it made- it brought about a measurable change in, you know, outcomes of their target beneficiaries ${ }^{\text {xix }}$.

US Charter schools and English academy schools are also drawn upon as models for new forms of educational governance in India - mobile policy entrepreneurs like Chester Finn and Mike Feinberg (CEO KIPP schools) bring 'stories' of reform successes to bear on education policy thinking in India.

... we are all informed by the experience in the US and the UK for charter schools and academies. And certainly that plays a role in terms of how we think about what to do in this area in India. Just yesterday we had a person at our CCS office, Dr Chester Finn, who is the president of the Fordham Institution 
in Washington D.C., which also works quite a lot in the charter school area. And he talked about what are the successes, what are the challenges that they are seeing so far in the US experience. (PS)

The network is a conduit for the dissemination and local legitimation and recontextualisation of these practices and methods - through people, events, visits, and publications (pamphlets blogs, research etc. etc.) and their local re-assembly (Holden 2009).

The initial (Akanksha) schools in 2007/2008, were heavily influenced by networks like KIPPxx, in particular. Shaheen Mistri (founder of Akanksha, CEO of TfI and Trustee of the ISLI) also has, you know, has a history in the US, she lived there for some years, went to high school there. (VG)

The mobility and redeployment of these forms, within specific programmes and in relation to future developments also brings into play opportunities for new careers and these developments also spin off many local business opportunities (Holden 2009) ${ }^{x \times i}$. For example, assessment and measurement is the business of Educational Initiatives ${ }^{x x i i}$ which is a partner in several programmes of school assessment, and PPPs are business opportunities for consultancy companies like BCG, McKinsey. McKinsey was involved in the Mumbai School Excellence Programme (MSEP), BCG was interested.

The Boston Consulting Group, which is the change management partner for this particular project (see below) started coming and talking to us just in terms of, you know, just for brainstorming, using us as a sounding board, in terms of learning from our experience in Mumbai. Therefore when the state came and pitched it to us for direct funding, it was something which has already been cocreated, we were very much a partner in the process. (PW)

This 'co-creation' is another kind of blurring of the boundaries between the state and the economy, between business and philanthropy, between policy interests and business interests. Ideas, sensibilities and money flow across these blurred boundaries.

\section{New governance}

Finally, but briefly, the ideas, forms and programmes in motion here, when reassembled constitute a reform ensemble which has general effects - most pertinently for modes of governance and concomitantly for the form and modalities 
of the state. The network and the mobilities sketched here are conduits for the import and re-contextualisation of new modes of governance. That is, a shift from 'the government of a unitary state to governance in and by networks' (Bevir and Rhodes 2003 p. 41). However, there is no absolute change here but rather a shift in the balance or mix between the different elements of government - bureaucracy markets and networks. The new mix brings a fragmented array of new players from business and philanthropy into the work of governance. These are, on a relatively small scale, examples of what Brenner, Peck and Theodore (2010 p. 335) call 'Regulatory experiments' that is 'place-, territory-, and scale-specific projects designed to impose, intensify, or reproduce market-disciplinary modalities of governance'. However, imposition is probably the wrong verb here. There is a considerable reliance on some degree of receptivity or enthusiasm for change on the part of individual state actors (as in the case of the MSEP), or some parts of the central or state local. The state is not a monolithic whole.

It's been very organic but only until McKinsey was brought on board and there was a very progressive additional municipal commissioner, who was looking after all of the education portfolio of the city of Mumbai, who was around- he was there from like 2009 to 2011 and he said that I want to transform the quality of learning that's taking place in all thirteen-hundred-plus municipal schools in this city. He got the State Bank of India to fund McKinsey's engagement and brought in McKinsey to conceptualise what they're calling now the School Excellence Programme (VG)

To give some further substance to this I want to say something about one point of activity within this network that involves some of the key players in collaboration around particular initiatives, a glimpse into the 'prosaic netherworlds of policy implementation' (Peck and Theodore 2012 p. 24). That is, a form of PPP within which non-state actors are taking on the running of state schools in Mumbai (as above) and latterly in South Delhi. Again such programmes often bring an array of global forms into play together.

We started our operations with a leadership intervention called School Leaders for India. We then branched out to the vouchers and the phonics programme soon after. About a year and a half ago we received an accountable grant from DFID, to run a quality assessment project in the state of Uttar Pradesh. And most recently we are in dialogue with the South Delhi Municipal Corporation, to set up a private-public partnership. (Amitav Vermani, ARK India and Education Alliance) 
So we have started funding something, with McKinsey, which is the state School Excellence Programme in the city of Mumbai. We see this in terms of systemic transformation by funding something similar in another geography (Delhi), in other schools. The Boston Consulting Group, which is the change management partner for this particular project, started coming and talking to us ... learning from our experience in Mumbai. (PW)

So we've actually collaborated with a few other like-minded funders, like Central Square Foundation, ARK and Omidyar Network in India, to set up a coalition, which is an independent entity funded by us (The Education Alliance), which is going to develop this whole ecosystem for PPP schools in India, working directly with cities. Creating all the regulatory structures for enabling the cities to be able to establish partnerships with private operators and at the same time bring more and more private operators to the table under the right incentive structure and regulatory structure so that they can start running some of these schools. (PW)

The two PPPs in Mumbai and Delhi are examples of the movement and mutation of Charter schools/Academies (as global forms and silver bullets) into India, with Dell and ARK, working with McKinsey and Boston Consulting, acting as policy intermediaries, drawing on 'evidence based' policy 'solutions' from the US and England. There are several other programmes of a similar kind operating in other parts of India.

Mumbai has played a bit of a pioneering role because the public-private partnership policy in Mumbai got passed in January 2013 and that was the first policy of its kind in the country, after which a bunch of other governments, including South Delhi and Gujarat and Haryana, have been trying to develop similar policies, consulting the Mumbai government, consulting us. Then, separately, Ashish has developed a broader vision for transformation of the education system in Delhi, which is not just South Delhi but it is all of Delhixxii. (AV)

The response to these initiatives is wide spread but uneven, cities and states vary in interest and enthusiasm with some becoming involved in several sorts of programmes as indicated above and others having no interest or participation. The nature of state involvement, degree of adaptation and reliance on 'outside' actors varies.

There are also other cities and states, which we are currently in discussion with for similar programmes. And also, cities and states where we may not be directly involved but the state government has taken our help to craft the programme and subsequently, they are driving it on their own or with other 
entities and so on. So this trend has started in India and there are a bunch of relevant programmes going on. In Haryana there's a programme that has just started, which we helped in shaping. (RV)

Bhanji (2012) makes the point that PPP agreements change the field they enter, and bring about a reallocation of authority. These are small scale examples of what Brenner, Peck and Theodore (2010 p. 335) call 'systems of inter-jurisdictional policy transfer' that is 'institutional mechanisms and networks of knowledge sharing through which neoliberal policy prototypes are circulated across places, territories, and scales, generally transnationally, for redeployment elsewhere'. There are several scales and ranges of mobility here, the movement of policy forms and ideas from (and between) the US and England, and movements within India, between cities and states. As practices of governing, initiatives of this sort are beginning to re-define the Indian state at various levels. They are part of the 'continual definition and redefinition of what is within the competence of the state' (Foucault in Gordon, Miller et al. (1991). Parts of the state are being reconfigured and reinvented in novel ways, at different speeds, from different starting points. There is another dimension of mobility involved here, that is, between sectors - again here we see the key role of a state enthusiast for change. This also points up some of the generality of the changes described here. There is nothing that special about education in terms of the mobility of neoliberalism and the reform of the state.

in the last ten/twelve years we have seen a lot of success with the publicprivate partnerships on the infrastructure side in building roads and so on. The roads landscape of India has changed dramatically because of public-private partnerships. And as a result I think this whole concept has become more favourably viewed and particularly the Planning Commission and a person called Gajendra Haldea who is really associated with the infrastructure publicprivate partnerships. There has been a lot of trust from them and he was also involved in developing the details of the MHRD secondary schools publicprivate partnership policy. Even though it's a different sector, in terms of influencing people's thinking that has played a role. (RV)

However, to reiterate these programmes do not signal once and for all systemic changes, rather they are policy rachets (Ball 2008) - small moves, experiments and initiatives that may be scaled up, and contribute over time to a more profound system re-engineering. Far from a dramatic 'roll-back' or a total 'hollowing out' of the state (Holliday 2000), this new model of governance implies a 'roll-out' of new structures and technologies of governance that redefine the roles and responsibilities of the state but, at the same time, resituate the state strategically in both normative and institutional terms. These are part of a deeper transformation of the political sphere, 
the 'de-governmentalisation of the state' (Rose 1996), and they are producing new forms of political organization in which governments no longer exert monopolistic control over statework. This involves repopulating and reworking existing policy networks, and giving primacy and legitimacy to the role of business or enterprise or philanthropy in the solution of 'wicked' social problems (like school improvement and social disadvantage). This is a move beyond both bureaucratic and market forms of coordination toward more flexible heterarchical relationships, within which responsibilities and processes of decision-making are shared by a heterogeneous mix of old and new policy actors, with the effect of re-balancing the governance mix (Ball and Junemann 2012).

\section{Discussion}

One small part of an extensive joined-up policy community, a discursive community, a 'globally integrated network' (Urry 2003) of highly interdependent actors and organisations, practices and forms, which are related together in diverse ways, has been sketched here. Starting with this community I have attempted or begun what Ong (2007) calls an analytics of assemblage rather than of structure or what Roy (2010) calls an 'ethnography of apparatus' - relating together practices, language, people and places, sites and events and organisational forms, and the labour of policy work which join up these within policy networks. I have tried to demonstrate the possibilities of network both as a method for the analysis of educational reform and governance, and a representation of actual social relations and sites of activity, and specifically in the Indian case an emergent form of governance - a heterarchy (see Ball and Junemann 2013). That is, this policy network is a set of interactions, interdependencies and exchanges and a form of power relations which do governing work and through which policy moves, or rather, is moved.

These network relations are not outside or over and against the local in any simple sense, they have multiple changing relations to and within 'the local' or in fact different locals. Indeed, what is local and global is changed/muddied by the relationships and movements traced here; 'it is not that the interrelations between objects occur in space and time; it is these relationships themselves which create/define space and time' (Massey 1992 p. 75). India now is a time and a place in which change is possible - there are policy entrepreneurs looking for/probing for openings for change, alert to policy windows (Kingdon 1995), and political actors at national and state levels willing to entertain new conceptions of policy and forms of governing. As Peck and Theodore (2012 p. 22) say a 'policy 'model' ... can only exist as a model once it has enrolled an "audience" of interlocutors and would-be emulators'. In India there are now interlocutors and emulators in play. Key network 
actors like Ashish Dhawan are active in the process of enrolment. The spaces of policy in India are being re-formed in the processes of change. In the indigenous language of the policy community, an 'ecosystem'xxiv is being created within which new forms of policy and of governing are being enacted. This is a new governing apparatus or dispositif within which new narratives about what counts as a 'good' policy are being articulated and validated (see Ball 2007), new forms of policy are made thinkable, new voices are given space within policy talk, and new forms of participation are created. A new mix of hierarchy, heterarchy and markets is being constructed (Ball and Junemann 2012)

These new 'reflexive, self-regulatory and horizontal' spaces of governance are a new historical formation that has repercussions for the objects and domains addressed. The means and methods of Indian education policy are changing. Concomitantly, new kinds of sociality and knowledge are being mobilised which have the power to interpolate individuals as new kinds of social, political and policy subjects. There is a re-allocation of authority in relation to running schools, bringing innovations and new practices to bear, measuring performance, doing policy and doing 'government'. That is, manoeuvrings around how education (students, parents, schools, teachers) should be governed, by whom, to what ends and with what means.

There is a proliferation of new sites in and in relation to India in which policy is being 'done' and a set of new 'policy technologies' and global forms (PPPs, philanthropic investment, leadership, brokering, incubation - scale partners, providers (chains), training, advocacy, platforms, etc.) that are moved through and between these sites. These technologies and forms are both the instruments and effects of networking, and specific articulations in practice of new policy discourses which contribute to the uneven development and transnational circulation of neoliberalized policy templates' (Brenner, Peck and Theodore 2010 p. 339) or as (Cook and Ward 2012) put it 'examples are translated into models, or into best or good practice, that are then wont to be replicated elsewhere'. These forms and technologies are re-instantiated through the various discursive performances of policy entrepreneurs, traveling technocrats and 'thought leaders', as 'solutions' to policy 'problems' (Clarke 2012). As I have tried to indicate, we are able to glimpse through these network relations some of the modes and means of policy mobility and the work involved in the 'assembling' of political rationalities, spatial imaginaries, calculative practices and subjectivities.

The people identified here who labour within and across these new sites of policy 'are sociologically complex actors, located in (shifting) organizational and political fields, whose identities and professional trajectories are often bound up with the policy positions and fixes they espouse' (Peck and Theordore 2010). That is to say, the networks are made up of 'embodied geographies' and by following the actors we can begin to 
see how ideas travel and orthodoxies become consolidated (see Ball (2016). I have also tried to indicate some of the forms of labour involved in assembling and reassembling the sociomaterial practices of educational reform - as in the PPPs in Delhi and Mumbai. As with (Larner and Laurie 2010 p. 224) work on engineers and privatization, this account indicates the 'centrality of multiple and shifting forms of expertise in the reconfiguring of political-economic institutions, ideas and techniques. In other words, 'These experts (like AD, SJ, AV, VR, PS) are enacting particular forms of "techno-politics" (Mitchell 2002) that link knowledge and expertise to political power in diverse and distinctive forms' (Larner and Laurie 2010 p. 223). In some cases, this expertise is drawing on organizational resources from business (McKinsey, Boston Consulting) and philanthropy (Dell, Omdiyar, ARK). While education policy analysis is beginning to have things to say about flows, spaces, states and institutions, much less attention has been devoted less to the lives and labour of the people producing the changing frames, practices and relationships through which policy work is shaped and done (see Rankin, 2003).

In all of this the flows and spaces and recontextualisations that link and intertwine local with global produce what Lingard and Sellar (2014) call new topologies of policy. Policy 'space is configured through the intersection of global and situated elements' (Ong 2007 p. 5). There is no claim of determination by a global form, rather different conditions of possibility. TFA, ARK, Dell, DfID, McKinsey, Omidyar, Boston Consulting etc., in India and elsewhere, are new intersectional agents and spaces of policy, and they establish multifaceted, interactive relationships with local actors (CCS, CSF, TfI, IISL, Bharti etc). This is not a story of simple hegemony, or one-way flows of policy, but rather 'there are multiple actors, multiple geographies and multiple translations involved in the processes of policy transfer' (Larner and Laurie 2010 p. 225). The space of analysis is not defined by geographical entities, but by the space configured through the intersection of global and situated elements - in India global, regional, national, state and city levels of policy intersect and diverge. As policies move, as new sites, new possibilities and sensibilities are established what Brenner, Peck and Theodore (2010 p. 339) call the 'context of context', that is 'the political, institutional, and juridical terrain within which locally, regionally, and nationally specific pathways of regulatory restructuring are forged' is being re-worked. DfID's support for market solutions, Gordon Brown's work as UN envoy, the willingness of some Indian states to work with business and philanthropic actors, as some of many small and on-going changes in the 'context of context', in the regulatory frameworks within which policy is thought and done.

As I have tried to illustrate here global policy networks are social and human constructions, they are complex, enduring and evolving connections between people, objects, and technologies across multiple and distant spaces and times (Law, 1994, p. 
24; Murdoch 1995, p. 745). However, such networks have to be constantly made and remade, the relations that constitute them are processual (Massey 2005). They are always under construction; 'always in the process of being made ... never finished; never closed' (Massey, 2005 p. 9). These intersecting and overlapping relations and interactions amplify the reform process and its constituent technologies and are 'held in place' by 'chains of on going effort' (Fenwick 2009) - meetings, events, conversations, visits, funding, alliances etc.. That is, 'the chains, circuits, networks, webs, and translations in and through which policy and its associated discourses and ideologies are made mobile and mutable' (McCann and Ward 2012). Thus, as McFarlane (2009 p. 562) argues, and as attempted here, we should be attending to 'the labour of assembling and reassembling sociomaterial practices that are diffuse, tangled and contingent'. Concomitantly this requires new forms of labour on the part of network researchers, new research strategies. However, process is not always easy to convey. What is offered here is a snapshot in the construction and evolutions of a fast-changing set of relationships and initiatives. Over and against the conceptualisation of networks as dynamic and evolving, network analysis is a constant struggle against, flatness, finishedness and order, and effort and imagination are also needed within research writing to maintain a sense of their 'throwntogetherness' and their evolution.

The case addressed here has been used to explore some different ways of thinking about and researching policy work. The aim has been to 'open up a set of issues, rather than to provide a definitive account' (Lingard, Sellar and Savage (2014 p. 711). The substantive analysis of the case remains under-developed - partly as a result of the limitations of space. However, what I am trying to do here is to outline some starting points and directions for further work. In particular, I have attempted to indicate what might be involved in the move from simply mapping networks to analyzing network dynamics and policy mobility - that is the labour of networking, network evolution, and the work that networks do in relation to there-imagining of policy and governance. Fundamental to this is a simple but important idea, that as policies move they change the sites and the landscape through which and across which they move.

\section{$\underline{\text { References }}$}

Amin, A. (2002). "Spatialities of globalisation." Environment and Planning A 34: 385-399.

Ball, S. J. (2012). Global Education Inc.. London, Routledge.

Ball, S. J. (2013). Foucault, Power and Education. New York, Routledge.

Ball, S. J. (2016). Labouring to Relate: neoliberalism, embodied policy and network dynamics. PEA Yearbook, Peabody.

Beck, U. (2006). Cosmopolitan Vision. Cambridge, Polity Press. 
Bennett, W. L. (2005). Social Movements beyond borders: Understanding two eras of transnational nationalism. Transnational Protest and Global Activism. Lanham: MD, Rowman and Littlefield: 203-226.

Bevir, M. and R. A. W. Rhodes (2003). "Searching for Civil Society: Changing Patterns of Governance in Britain." Public Administration 81(1): 41-62.

Bhanji, Z. (2012). "Transnational private authority in education policy in Jordan and South Africa: A case Microsoft Corporation." Comparative Education Review 56(2): 300-319.

Castells, M. (2004). Power and politics in the network society. Ralph Miliband Memorial Lecture. London School of Economics and Political Science. 14 March. Available at http://annenberg.usc.edu/images/faculty/facpdfs/Castells-LSElecture.pdf.

Clarke, M. (2012). "The (absent) politics of neoliberal education policy." Critical Studies in Education 53(3): 297-310.

Cook, I. R. and K. Ward (2012). "Conferences, information infrastructures and mobile policies: the process of getting Sweden 'BID Ready'." European Urban and Regional Studies 19(2): 137-152.

Della Porta, D. and M. Diani (1999). Social Movements: an introduction. Blackwell, Oxford.

Fenwick, T. (2009). "Making to measure? Reconsidering assessment in professional continuing education." Studies in Continuing Education 31(3): 101-118.

Gordon, C., P. Miller, et al., Eds. (1991). The Foucault Effect: Studies in Governmentality. Brighton, Harvester/Wheatsheaf.

Fenwick, T. (2009). "Making to measure? Reconsidering assessment in professional continuing education." Studies in Continuing Education 31(3): 101-118.

Grek, S. (2013). "Expert moves: international comparative testing and the rise of expertocracy." Journal of Education Policy 28(5): 695-709.

Grek, S. and J. Ozga (2010). "Re-Inventing Public Education: The New Role of Knowledge in Education Policy Making." Public Policy and Administration 25(2): 271-288.

Hogan, A. (2015). The role of edu-business in new global education policy networks. School of Education. Brisbane, University of Queensland. PhD.

Hogan, A., S. Sellar, et al. ((forthcoming)). "Commercialising Comparison: Pearson, edu-business and new policy spaces in education."

Holden, C. (2009). "Exporting Public-Private Partnerships in Healthcare: Export Strategy and Policy Transfer " Policy Studies 30(3): 313-332.

Holliday, I. (2000). "Is the British State Hollowing out?" Political Quarterly(71): 2.

Kingdon, J. W. (1995). Agendas, alternatives, and public policies. New York, HarperCollins.

Kretchmar, K., B. Sondel, et al. (2014). "Mapping the terrain: Teach for America, charter school reform, and corporate sponsorship." Journal of Education Policy 29(6).

Larner, W. and N. Laurie (2010). "Travelling Technocrats, embodied knowledges: globalising privatisation in telecoms and water." Geoforum 41: 218-226.

Law, J. 1994. Organizing Modernity. Oxford: Blackwell. 
Lingard, B. and S. Rawolle (2011). "New Scalar Politics: Implications for education policy." Comparative Education 47(4): 1-18.

Lingard, B. and S. Sellar (2014). "Representing Your Country: Scotland, PISA and New Spatialities of Educational Governance." Scottish Educational Review 46(1): $1-5$.

MacFarlane, C. (2009). "Translocal assemblages: space, power and social movements." Geoforum 40: 561-567.

Marcus, G. (1995). "Ethnography in/of the World System: The emergence of multi-cited ethnography." Annual Review of Anthropology 24: 95-117.

Massey, D. (1992). Space, Place and Gender. Cambridge, Polity Press.

Massey, D. (2005). For Space. London, Sage.

McCann, E. and K. Ward (2012). "Assembling urbanism: following policies and 'studying through' the sites and situations of policy making." Environment and Planning A 44(1): 42-51.

Mitchell, K. (2003). "Educating the national citizen in neoliberal times: from the multicultural self to the strategic cosmopolitan." Transactions of the Institute of British Geographers 28(4): 387-403.

Mitchell, T. (2002). Rule of Experts: Egypt, Techno-Politics, Modernity. Berkeley: CA, University of California Press.

Murdoch, J. 1995. 'Actor-networks and the Evolution of Economic Forms: Combining Description and Explanation in Theories of Regulation, Flexible Specialisation, and Networks', Environment and Planning A, 27: 731-57.

Olmedo, A., P. Bailey, et al. (2013). "To Infinity and beyond...: Heterarchical Governance, the Teach for All Network in Europe and the Making of profits and minds." European Educational Research Journal 12(4): 492512.

Ong, A. and S. Collier (2005). Global Assemblages: technology, politics and ethics as anthropological problems. Malden, Blackwell.

Owen-Smith, J. and W. W. Powell (2004). "Knowledge Networks as Channels and Conduits: The Effects of Spillovers in the Boston Biotechnology Community." Organizational Science 15(1): 5-21.

Peck, J. (2003). "Geography and public policy: mapping the penal state." Progress in Human Geography 27(2): 222-232.

Peck, J. and N. Theordore (2010). "Mobilizing Policy: models, methods and mutations." Geoforum 41: 169-174.

Prince, R. (2010). "Policy Transfer as Policy Assemblage: Making policy for the creative industries in New Zealand." Environment and Planning A 42(1): 169-186.

Rankin, K. (2003). "Anthropologies and geographies of globalization." Progess in Human Geography 27(6): 708-734.

Reckhow, S. (2013). Follow the Money: How foundation dollars change public school policies. New York, Oxford University Press.

Rose, N. (1996). Governing "advanced" liberal democracies. Foucault and Political Reason: Liberalism, neo-liberalism and rationalities of government. A. Barry, T. Osborne and N. Rose. London, UCL Press.

Schriewer, J. (2014). "Niether orthodoxy nor randomness: different logics of conducting comparative and international studies in education." Comparative Education 50(1): 84-101. 
Stark, D. (1998). Heterarchy: Distributing Authority and Organzing Diversity. The Biology of Business. J. H. Clippinger. New York, John Wiley.

Stone, D. (2004). "Transfer agents and global networs in the 'transnationalization' of policy." Journal of European Public Policy 11(3): 545-566.

Stuart, T. E. and O. Sorenson (2003). "The geography of opportunity: Spatial heterogeneity in founding rates and performance of biotechnology firms." Research Policy 32(1): 229-253.

Urry, J. (2003). "Social networks, travel and talk." British Journal of Sociology 54(2): 155-175.

Urry, J. (2007). Mobilities. Cambridge, Polity Press.

Verger, A. (2012). "Framing and selling global education policy: the promotion of public-private partnerships for education in low income countries." Journal of Education Policy 27(1): 109-130.

Verger, A. and M. Curran (2014). "New public management as Global education policy: its adoption and re-contextualisation in a Southern European setting." Critical Studies in Education Policy.

Williams, P. (2002). "The competent boundary spanner." Public Administration 80(1): 103-124.

\footnotetext{
i I am very aware of the various telling criticisms of the ontology of networks and I have sought to address and incorporate some of these in the way networks are conceptualized and researched here. Rather than import the idea of assemblage, as a new language of description for network analysis, I have attempted to elaborate on the characteristics of the network to encompass some aspects of the sensibility of assemblage.

ii More precisely this is one version, one assembly of what are a set of overlapping networks of various kinds, that focuses on relations related to or focused on processes of education policy.

iii See: http://download.ei-

ie.org/Docs/WebDepot/ei_palf_publication_web_pages_01072015.pdf.

iv See: http://educatingthegatesfoundation.com/tag/wayne-au/),

$\mathrm{v}$ The visits to these events were undertaken by my research colleagues Carolina Junemann and Diego Santori.

vi In the data we see "how different actors and activists narrativise assemblages through spatial metaphors and organising logics of, for example, scale, network, federation and so on' (McFarlane 2009 p. 566).

vii On a national level the network contributes to the proto, roll back - and roll out stages of neoliberalisation.

viii See: http://www.ficci.com/spdocument/20380/CSF-FICCI_Public-PrivatePartnerships_Mar-2014.pdf.

ix Justin van Fleet is Chief of Staff to the UN Special Envoy for Global Education, Rt. Honourable Gordon Brown, and nonresident fellow at the Center for Universal Education, Brookings Institution and formerly deputy chair for education at the Clinton Global Initiative.

x See: http://www.teachingleaders.org.uk.

xi See: https://en.wikipedia.org/wiki/Bob_Pattillo.
} 
xii Katelyn Donnelly leads the Pearson Affordable Learning Fund (PALF), which was launched in May 2012 with a mandate to invest in the creation and servicing of low-cost private schools and education solutions around the globe. She was recently named as one of the world's most influential under 30 year olds working in education.

xiii Sir Michael Barber joined Pearson in September 2011 as Chief Education Advisor, and is Chairman of the Pearson Affordable Learning Fund. Prior to Pearson, he was Head of McKinsey's global education practice.

xiv Jay Kimmelman is Co-Founder and CEO of Bridge International Academies, the largest chain of private schools in Africa (see Junemann 2015).

xv We can follow 'plots' through these paths and chains outwards and inwards and the literal circulation of people and things. These paths can make ideological homophily and heterogeneity visible. For example, Central Square Foundation funds Teach for India, which is part of the Teach for All network which emerged from Teach for America, which is heavily funded by the Gates and Broad foundations, who are also advocates and funders of US Charter schools, including KIPP, who have supported the work of Akanksha, and whose Chief Executive Mike Feinberg has visited ARK India and CSF etc. etc.

xvi M-CRIL India is a micro-finance credit ratings firm, see:

http://www.educationinnovations.org/program/school-assessment-schoolimprovement-sasi

xvii http://www.theugandanjobline.com/2014/04/british-council-dfid-projectjobs.html.

xviii See http://www.teachthought.com/blended-learning-2/the-definition-ofblended-learning/

xix http://beta.livemint.com/Opinion/zKv5gl4TpzYiu4riO0gJ60/Target-educational-

outcomes-not-inputs-in-the-budget.html.

xx See http://www.houstonchronicle.com/news/houston-

texas/houston/article/KIPP-leaders-help-global-partners-adopt-its-model4547647.php

xxi PALF.

xxii EI is also working with leading organizations like World Bank, Michael and Susan Dell Foundation, Google, Azim Premji Foundation, Duke University, USA and is doing large scale assessment projects with various State Governments. In the last 12 years, EI has assessed over 2 million students, with more than 55,000 students experiencing personalized learning through Mindspark in cities like Lansing and Michigan, USA.

Today, EI has worked with over 3000 schools with over 3.5 lac students taking the EI's International Benchmarking Test - ASSET every year and has a presence in UAE, Kuwait, Singapore and USA. EI, in association with Google, has also conducted one of the largest studies to know the student learning levels in government schools in 21 states of India, along with a Students Learning in Metros Study conducted in association with Wipro. The Government of Bhutan has also partnered with EI to conduct Student and Teachers Assessments on annual basis. (http://www.ei-india.com/about/) 
xxiii CSF has published a report Public-Private Partnerships in School Education: Learning and Insights for India (See more at: http://www.centralsquarefoundation.org/publications/\#sthash.acNUB7Fp.dpuf. xxiv E.g. https://www.edsurge.com/n/2013-09-24-building-a-perspectful-edtechecosystem-in-india 